\section{Corticosteroid use in neurology: how dogs are referrals to a neurology service?}

\author{
Uso de corticosteroides em afecções neurológicas: como os \\ cães são referidos a um serviço de neurologia?
}

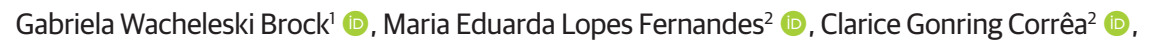
Anna Julia Rodrigues Peixoto ${ }^{2}$ (D), Alex Gradowski Adeodato 3 (D), Daniel de Almeida Balthazar ${ }^{4}$ (D), Marta Fernanda de Albuquerque da Silva ${ }^{4}$ (D) \& Cássia Maria Molinaro Coelho ${ }^{4}$ (D)

'Veterinary, Master's Degree Student. Programa de Pós-graduação em Medicina Veterinária PPGMV, Universidade Federal Rural do Rio de Janeiro - UFRRJ, Seropédica, RJ, Brasil

² Veterinary, PhD Student. Programa de Pós-graduação em Medicina Veterinária - PPGMV, Universidade Federal Rural do Rio de Janeiro - UFRRJ, Seropédica, RJ, Brasil

${ }^{3}$ Veterinary, Dsc. CRV Imagem, Rio de Janeiro, RJ, Brasil

${ }^{4}$ Veterinary, Dsc. Departamento de Medicina e Cirurgia Veterinária, Universidade Federal Rural do Rio de Janeiro - UFRRJ, Seropédica, RJ, Brasil

\begin{abstract}
Corticosteroids are drugs widely used in veterinary neurology due to their recognized anti-inflammatory, immunosuppressive and analgesic effects. However, their use in high doses and for long term may result in undesirable side effects. This study describes the prevalence of dogs with neurologic diseases referred to a veterinary neurology service with previous prescriptions for corticosteroids. In this retrospective study 284 medical records of dogs were evaluated in the period between August 2017 and April 2019. Of these, 194 (68\%) dogs had already received medical care from a clinician and 100 (52\%) had previously been prescribed corticosteroids. After diagnosis at the reference service, the corticosteroid dose was suspended in $28 \%$ of the cases, adjusted in $41 \%$ and maintained in $31 \%$. Dogs receiving immunosuppressive doses were the most affected and in $71 \%$ and $21 \%$ of the cases, their medication was adjusted or suspended, respectively. In conclusion, the therapy for neurological diseases is still strongly associated with the indiscriminate use of corticosteroids, without the dosage correlated to the desired effect.
\end{abstract}

Keywords: glucocorticoids, neurologic diseases, anti-inflammatory, immunosuppressive, canine.

\section{Resumo}

Os corticosteroides são fármacos muito utilizados na neurologia veterinária devido a sua reconhecida potência anti-inflamatória, imunossupressora e analgésica, porém, seu uso em doses altas e a longo prazo pode determinar efeitos indesejáveis e desordens em outros sistemas. Este trabalho descreve a prevalência de cães com afecções neurológicas encaminhados a um serviço de neurologia veterinária com prescrição prévia de corticosteroides. O estudo foi conduzido retrospectivamente a partir do atendimento de cães no período de agosto de 2017 a abril de 2019. Ao todo 284 prontuários foram avaliados. Destes, 194 (68\%) pacientes já possuíam atendimento por outro veterinário, sendo que, 100 (52\%) apresentavam prescrição para o uso da medicação. Após o diagnóstico, a dose foi suspensa em $28 \%$ dos casos, ajustada em $41 \%$ e mantida em $31 \%$. Os cães com prescrição prévia de doses imunossupressoras foram os mais alterados, sendo a medicação ajustada ou suspensa em $71 \%$ e $21 \%$ dos casos, respectivamente. Conclui-se que a terapêutica para afecções neurológicas ainda está fortemente associada à administração indiscriminada de corticosteroides, sem uma correlação da dose com o efeito desejado.

Palavras-chave: glicocorticoides, doenças neurológicas, anti-inflamatório, imunossupressor, canino.

\section{Introduction}

Steroidal anti-inflammatory drugs, also known as corticosteroids, are commonly used in veterinary medicine to treat neuropathies due to their anti-inflammatory, immunosuppressive and analgesic efficacy (Platt et al., 2005; Jeffery, 2014). In addition, corticosteroids provide protection against free radicals (Olby, 1999), reduce intracranial pressure by decreasing the production of cerebrospinal fluid (CSF), help maintain the integrity of the microvasculature (Platt et al., 2005) and, one of the more important effects, is the reduction of the leukocyte expression and function, which effects both the innate and acquired immunity (Behrend \& Kemppainen, 1997).
How to cite: Brock, G. W., Fernandes, M. E. L., Correa, C. G., Peixoto, A. J. R., Adeodato, A. G. Balthazar, D. A., Silva, M. F. A., Coelho, C. M. M. (2020). Corticosteroid use in neurology: how dogs are referrals to a neurology service? Brazilian Journal of Veterinary Medicine, 42, e106520. http:// dx.doi.org/10.29374/2527-2179.bjvm106520

Fonte de financiamento: This study was financed in part by the Coordenação de Aperfeiçoamento de Pessoal de Nível Superior - Brasil (CAPES) - Finance Code 001

Conflict of interests: No conflict of interests declared concerning the publication.

Received: July 30, 2019.

Accepted: February 25, 2020.

Thestudy was carried out at Hospital Veterinário de Pequenos Animais, Universidade Federal Rural do Rio de Janeiro, Seropédica, RJ, Brasil.

\section{*Correspondence}

Gabriela Wacheleski Brock

Universidade Federal Rural do Rio de Janeiro - UFRRJ

Campus Seropédica, CEP 23890-000 -

Seropédica (RJ), Brasil

E-mail: gwacheleski@gmail.com
Copyright Brock et al. This is an Open Access article distributed under the terms of the Creative Commons Attribution Non-Commercial License which permits unrestricted non-commercial use, distribution, and reproduction in any medium provided the original work is properly cited. 
Depending on the dose and duration of corticosteroid therapy, animals may experience side effects, such as myopathies, tendon and ligament laxity, weight gain, hyperglycemia and secondary infections, which can mask and mimic the neurological signs (Jeffery, 2014). Recent studies with dogs have shown that corticosteroid therapy alone can induce behavioral and cognitive changes (Notari et al., 2015; Notari et al., 2016). In addition, such changes can mask symptoms and findings in complementary tests, as determining an inconclusive CSF cytology, for example, thus making some diagnoses difficult (Platt et al., 2005; Jeffery, 2014). This study discusses the use of corticosteroids for neurologic disorders prescribed by veterinarians for dogs that were referred to the Veterinary Hospital of the Federal Rural University of Rio de Janeiro (UFRRJ).

\section{Material and methods}

This retrospective study evaluated the medical records of dogs with neurological dysfunctions that had been referred to the Neurology Service at the Veterinary Hospital of UFRRJ, from August 2017 to April 2019. The inclusion "Criteria" stated that the same team should treat and monitor the animals under supervision of a professional who has 20 years of experience in the specialty (AGA). The medical records of the dogs showed which animals had been referred to the Neurology Service by clinicians and, of these, which had been prescribed corticosteroids. The prescribed dosages were classified as anti-inflammatory (0.5-1.0 mg/kg/d) or immunosuppressive (2.0-4.0 mg/kg/d) (Boothe, 2011; Plumb, 2011). After the diagnosis (confirmed or presumptive) by the Neurology Service a decision was made as to whether to suspend the medication, readjust the dosage to anti-inflammatory or immunosuppressive doses or maintain it following the recommendations found in the literature. The animals were also evaluated according to sex, age, breed and grouped according to the etiology of the disease, using the VITAMIN-D acronym (Table 1) (Dewey \& Da Costa, 2016). The results were described and discussed using descriptive statistics.

\section{Results}

This study evaluated 284 medical records of dogs over the study period. The most prevalent characteristics are shown in Table 2. The majority of the cases (68\% - 194/284) had been attended by at least one clinician and 52\% (100/194) of these had been prescribed corticosteroids. Prednisone and dexamethasone were the most commonly prescribed corticosteroids. Following clinical and complementary examinations at the UFFRJ Veterinary Hospital, the previous diagnoses were confirmed in 59\% of the dogs (59/100) and were presumptive in 41\% (41/100).

The corticosteroid doses previously prescribed $(n=100)$ was suspended in 28 cases $(28 \%)$, adjusted in 41 (41\%) and maintained in 31 (31\%) of the animals (Figure 1A).

The protocols that were altered the most were for dogs that had been prescribed immunosuppressive doses. In $71 \%$ of these cases, the dose was reduced to an anti-inflammatory effect and medication was suspended in $21 \%$ of the cases (Figure 1B). These changes made in the prescriptions for corticosteroid therapy, according to the etiology and diagnosis, are described in Table 3.

Table 1. Description of the VITAMIN-D acronym based on pathophysiologic mechanisms of neurologic diseases in small animals (Dewey \& Da Costa 2016).

\begin{tabular}{|c|c|c|}
\hline & ETIOLOGY & EXAMPLES \\
\hline $\mathbf{V}$ & Vascular & $\mathrm{CVD}^{1}$ (ischemic or hemorrhagic), FCEM ${ }^{2}$ \\
\hline I & Inflammatory/infectious & MUO3$^{3}$, Distemper, Discospondylitis \\
\hline $\mathrm{T}$ & Traumatic; toxic & $\mathrm{TBI}^{4}$; Metronidazole toxicity \\
\hline A & Anomaly & Hydrocephalus, Atlantoaxial instability \\
\hline M & Metabolic & Hepatic encephalopathy \\
\hline I & Idiopathic & Idiopathic epilepsy, Idiopathic vestibular disease \\
\hline $\mathbf{N}$ & Neoplastic & Primary and secondary (metastatic) brain/spinal tumors \\
\hline $\mathbf{D}$ & Degenerative & IVDD ${ }^{5}$, Degenerative myelopathy, Cognitive dysfunction \\
\hline
\end{tabular}

${ }^{1}$ Cerebrovascular disease; ${ }^{2}$ Fibrocartilaginous embolic myelopathy; ${ }^{3}$ Meningoencephalomyelitis of unknown origin; ${ }^{4}$ Traumatic brain injury; ${ }^{5}$ ntervertebral disc disease. 
Table 2. Characteristics of 284 dogs with neurological signs referred to the UFRRJ Veterinary Hospital, from August 2017 to April 2019. Seropédica, RJ.

\begin{tabular}{|c|c|c|c|c|c|c|c|}
\hline Age & Total & Males & Females & Small breeds ${ }^{1}$ & Medium breeds ${ }^{2}$ & Large breeds $^{3}$ & Mixed breed ${ }^{4}$ \\
\hline o-2years old & 71 & 38 & 33 & 20 & 16 & 5 & 30 \\
\hline 2-5years old & 86 & 41 & 45 & 22 & 11 & 9 & 44 \\
\hline 5-10 years old & 81 & 50 & 31 & 29 & 11 & 13 & 28 \\
\hline$>10$ years old & 46 & 25 & 21 & 17 & 8 & 2 & 19 \\
\hline TOTAL & 284 & 154 & 130 & 88 & 46 & 29 & 121 \\
\hline
\end{tabular}

${ }^{1}$ breeds up to $10 \mathrm{~kg} ;{ }^{2}$ breeds between 11 and 25 kg; ${ }^{3}$ breeds over $26 \mathrm{~kg} ;{ }^{4}$ crossbreed and mixed breed dogs. Source: Royal Canin, 2019.

Table 3. Characterization of the diagnoses, confirmed and presumptive, of dogs with neurologic diseases referred with a corticosteroid prescription ( $\mathrm{n}=100$ ) to the Neurology Service at the Veterinary Hospital of UFRRJ, from August 2017 to April 2019. Seropédica, RJ.

\begin{tabular}{|c|c|c|c|c|c|c|c|}
\hline \multirow{2}{*}{ Etiology } & \multirow{2}{*}{ Total cases } & \multicolumn{3}{|c|}{ Confirmed diagnoses } & \multicolumn{3}{|c|}{ Presumptive diagnosis } \\
\hline & & Maintained & Adjusted & Suspended & Maintained & Adjusted & Suspended \\
\hline Vascular & 3 & 0 & 0 & 1 & 0 & 2 & 0 \\
\hline Inflammatory/Infectious & 26 & 1 & 7 & 7 & 5 & 4 & 2 \\
\hline Traumatic & 21 & 2 & 9 & 8 & 0 & 1 & 1 \\
\hline Toxic & 4 & 0 & 0 & 4 & 0 & 0 & 0 \\
\hline Anomaly & 1 & 0 & 0 & 0 & 0 & 0 & 1 \\
\hline Metabolic & 1 & 0 & 0 & 1 & 0 & 0 & 0 \\
\hline Idiopathic & 2 & 0 & 0 & 1 & 0 & 1 & 0 \\
\hline Neoplastic & 13 & 4 & 2 & 0 & 1 & 6 & 0 \\
\hline Degenerative & 29 & 7 & 5 & 0 & 11 & 4 & 2 \\
\hline TOTAL & 100 & 14 & 23 & 22 & 17 & 18 & 6 \\
\hline
\end{tabular}

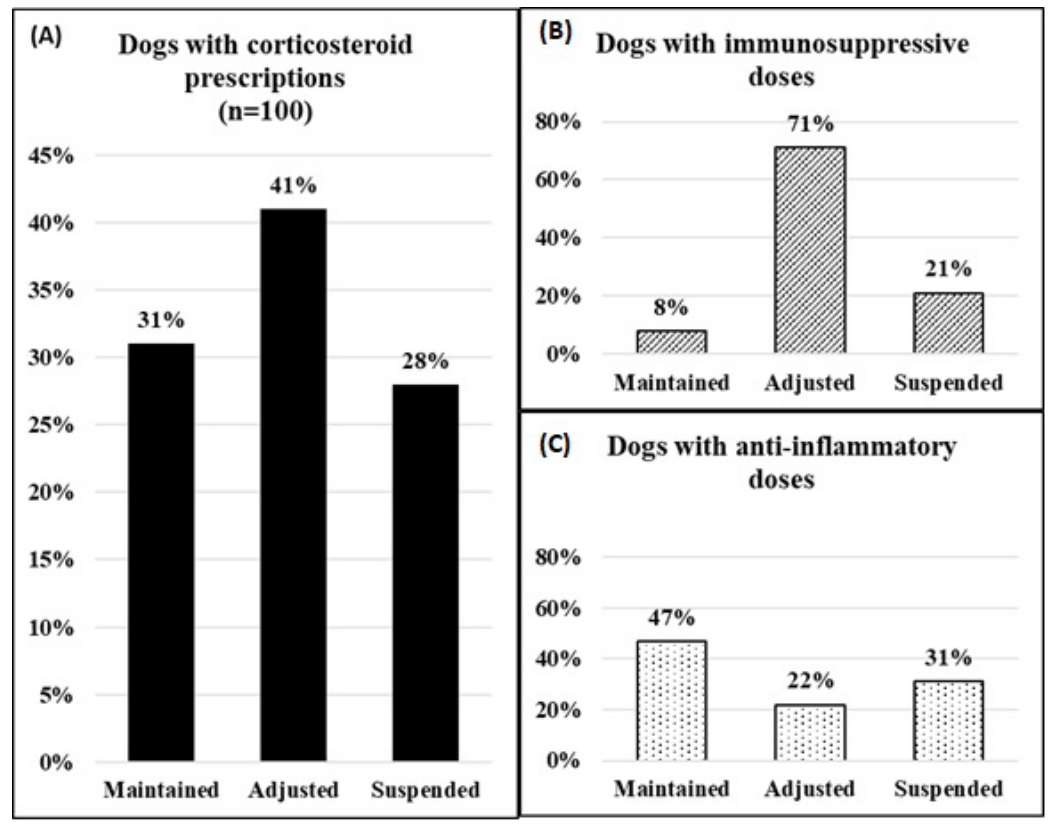

Figure 1. Adjustments made to the steroidal therapy prescribed to dogs ( $\mathrm{n}=100)$ referred to the Neurology Service at the Veterinary Hospital of UFRRJ, from August 2017 to April 2019. Seropédica, RJ. 


\section{Discussion}

The results of this study demonstrate that from the prospective of veterinary neurologists, there is an indiscriminate use of corticosteroids by veterinarians for dogs with neurological diseases. Although corticosteroids might, in theory, benefit animals for most neurological disorders, in some cases there is still no consistent clinical evidence to support their use. In neurologic trauma, the use remains controversial. In the physiology of traumatic brain injury (TBI), for example, the neurological damage can worsen due to the effects of the secondary injury (Sande \& West 2010; Difazio \& Fletcher 2013; Kuo et al., 2018). Despite the established benefits of corticosteroids in controlling the secondary injury (i.e., inhibiting lipid peroxidation) (Hanz et al., 2014), some studies have shown that their administration can potentiate neuronal damage by making neurons more vulnerable to metabolic insults and inhibiting the remyelination of injured neurons (Payne et al., 2003). The Corticosteroid Randomization After Significant Head Injury (CRASH) study demonstrated that the use of high doses of methylprednisolone in humans with severe TBI were associated with increased mortality, and did not show any clinical benefit (Roberts et al., 2004; Edwards et al., 2005); furthermore, steroidal therapy is not recommended for humans with TBI (Hoshide et al., 2016; Carney et al., 2017). Since then, this information has been extended to veterinary medicine. Nonetheless, there are still no clinical studies related to the use of corticosteroids at anti-inflammatory doses for the treatment of TBI in dogs.

The results of this study have also demonstrated a tendency of clinicians to initiate therapy with immunosuppressive doses. However, after the diagnosis these doses were adjusted in $71 \%$ of cases and suspended in 21\% (Figure 1B). In some inflammatory diseases due to infections (i.e. bacterial, fungal), immunosuppression can cause extension of the lesion and disease progression; however, the anti-inflammatory effects may reduce clinical signs by decreasing intracranial pressure and tissue inflammation (Platt et al., 2005; Jeffery 2014). In contrast, in inflammatory diseases of unknown and immune-mediated causes (ie, meningoencephalomyelitis of unknown origin) there is a significant improvement in neurological signs with the administration of immunosuppressive doses, and this is considered the initial therapy of choice (Higginbotham et al., 2007; Schatzberg, 2010; Coates \& Jeffery, 2014; Cornelis et al., 2019; Vitale \& Foss 2019). In cases of central nervous system's tumors, corticosteroids can be used in an anti-inflammatory doses to control secondary conditions of acquired hydrocephalus and peritumoral vasogenic edema (Koehler, 1995) as well as reducing associated intracranial pressure (Ropper et al., 2014), thus minimizing the neurological signs (Platt \& Olby, 2012; Dewey \& Da Costa, 2016).

There are cases where steroidal therapy is not indicated. In cerebrovascular diseases (ie, stroke or hemorrhage), although corticosteroids are commonly administered they have no effect on cytotoxic edema and they can alter the size of the lesion, which makes any beneficial use in vascular diseases questionable (Garosi, 2005; Hillock et al., 2006; Boudreau, 2018).

Due to the retrospective nature of our study, the main limitation was to define whether the prescription of corticosteroids, especially for those whose medication was adjusted or discontinued, was harmful to the progression of their cases or not, as this information was not available in the medical records.

Based on the results of this study, a precise diagnosis of the neurologic disease should be carried out before any pharmacological therapy with corticosteroids is prescribed and if indicated, they should be administered in an appropriate regimen.

\section{Conclusion}

These results suggest that in primary care practice the therapy recommended by veterinarians for neurologic diseases is still strongly associated with the administration of corticosteroids. This is often due to a lack of an accurate diagnosis and without correlating the dosage to the desired effect. The corticosteroid therapy without proper diagnosis may be detrimental to the prognosis of the dog.

\section{References}

Behrend, E. N., \& Kemppainen, R. J. (1997). Glucocorticoid therapy: Pharmacology, indications and complications. The Veterinary Clinics of North America. Small Animal Practice, 27(2), 187-213. http://dx.doi.org/10.1016/S01955616(97)50027-1. PMid:9076903. 
Boothe, D. M. (2011). Small Animal Clinical Pharmacology and Therapeutics (2nd ed.). Philadelphia: Saunders.

Boudreau, C. E. (2018). An update on cerebrovascular disease in dogs and cats. The Veterinary Clinics of North America. Small Animal Practice, 48(1), 45-62. http://dx.doi.org/10.1016/j.cvsm.2017.08.009. PMid:29056397.

Carney, N., Totten, A. M., O'reilly, C., Ullman, J. S., Hawryluk, G. W. J., Bell, M. J., Bratton, S. L., Chesnut, R., Harris, O. A., Kissoon, N., Rubiano, A. M., Shutter, L., Tasker, R. C., Vavilala, M. S., Wilberger, J., Wright, D. W., \& Ghajar, J. (2017). Guidelines for the management of severe traumatic brain injury. Neurosurgery, 80(1), 6-15. http:// dx.doi.org/10.1227/NEU.0000000000001432. PMid:27654000.

Coates, J. R., \& Jeffery, N. D. (2014). Perspectives on meningoencephalomyelitis of unknow origin. The Veterinary Clinics of North America. Small Animal Practice, 44(6), 1157-1185. http://dx.doi.org/10.1016/j.cvsm.2014.07.009. PMid:25239815.

Cornelis, I., Van Ham, L., Gielen, I., De Decker, S., \& Bhatti, S. F. M. (2019). Clinical presentation, diagnostic findings, prognostic factors, treatment and outcome in dogs with meningoencephalomyelitis of unknown origin: A review. Veterinary Journal, 244, 37-44. http://dx.doi.org/10.1016/j.tvjl.2018.12.007. PMid:30825893.

Dewey, C. W., \& Da Costa, R. C. (2016). Practical guide to canine and feline neurology (3rd ed.). Iowa: Blackwell Publishing.

Difazio, J., \& Fletcher, D. J. (2013). Updates in the management of the small animal patient with neurologic trauma. The Veterinary Clinics of North America. Small Animal Practice, 43(4), 915-943. http://dx.doi.org/10.1016/j. cvsm.2013.03.002. PMid:23747266.

Edwards, P., Arango, M., Balica, L., Cottingham, R., El-Sayed, H., Farrell, B., Fernandes, J., Gogichaisvili, T., Golden, N., Hartzenberg, B., Husain, M., Ulloa, M. I., Jerbi, Z., Khamis, H., Komolafe, E., Laloë, V., Lomas, G., Ludwig, S., Mazairac, G., Sanchéz, M. A. M., Nasi, L., Olldashi, F., Plunkett, P., Roberts, I., Sandercock, P., Shakur, H., Soler, C., Stocker, R., Svoboda, P., Trenkler, S., Venkataramana, N. K., Wasserberg, J., Yates, D., \& Yutthakasemsunt, S. (2005). Final results of MRC CRASH, a randomized placebo-controlled trial of intravenous corticosteroid in adults with head injury-outcomes at 6 months. Lancet, 365, 1957-1959.

Garosi, L. (2005). Cerebrovascular disease in dogs and cats. The Veterinary Clinics of North America. Small Animal Practice, 40(1), 65-79. http://dx.doi.org/10.1016/j.cvsm.2009.09.001. PMid:19942057.

Hanz, Z., Lat, I., \& Pollard, S. R. (2014). Safety and efficacy of corticosteroid use in neurologic trauma. Journal of Pharmacy Practice, 27(5), 487-495. http://dx.doi.org/10.1177/0897190013516500. PMid:25374988.

Higginbotham, M. J., Kent, M., \& Glass, E. N. (2007). Noninfectious inflammatory central nervous system diseases in dogs. Compendium, 29(8), 488-497. PMid:17849703.

Hillock, S. M., Dewey, C. W., Stefanacci, S. D., \& Fondavaro, J. D. (2006). Vascular encephalopathies in dogs: Diagnosis, treatment and prognosis. Compendium, 28(3), 208-216.

Hoshide, R., Cheung, V., Marshall, L., Kasper, E., \& Chen, C. C. (2016). Do corticosteroids play a role in the management of traumatic brain injury? Surgical Neurology International, 7(1), 84. http://dx.doi.org/10.4103/21527806.190439. PMid:27656315.

Jeffery, N. D. (2014). Corticosteroid use in small animal neurology. The Veterinary Clinics of North America. Small Animal Practice, 44(6), 1059-1074. http://dx.doi.org/10.1016/j.cvsm.2014.07.004. PMid:25239816.

Koehler, P. J. (1995). Use of corticosteroids in neuro-oncology. Anti-Cancer Drugs, 6(1), 19-33. http://dx.doi. org/10.1097/00001813-199502000-00002. PMid:7756680.

Kuo, K. W., Bacek, L. M., \& Taylor, A. R. (2018). Head trauma. The Veterinary Clinics of North America. Small Animal Practice, 48(1), 111-128. http://dx.doi.org/10.1016/j.cvsm.2017.08.005. PMid:28985897.

Notari, L., Burman, O., \& Mills, D. S. (2015). Behavioural changes in dogs treated with corticosteroids. Physiology \& Behavior, 151, 609-616. http://dx.doi.org/10.1016/j.physbeh.2015.08.041. PMid:26344646.

Notari, L., Burman, O., \& Mills, D. S. (2016). Is there a link between treatments with exogenous corticosteroids and dog behaviour problems? The Veterinary Record, 179(18), 462-471. http://dx.doi.org/10.1136/vr.103768. PMid:27634351.

Olby, N. (1999). Current concepts in the management of acute spinal cord injury. Journal of Veterinary Internal Medicine, 13(5), 399-407. http://dx.doi.org/10.1111/i.1939-1676.1999.tb01453.x. PMid:10499720.

Payne, R. S., Tseng, M. T., \& Schurr, A. (2003). The glucose paradox of cerebral ischemia: evidence for corticosterone involvement. Brain Research, 971(1), 9-17. http://dx.doi.org/10.1016/S0006-8993(03)02276-5. PMid:12691832.

Platt, S. R., \& Olby, N. J. (2012). BSAVA Manual of Canine and Feline Neurology (4rd ed.). United Kingdom: Quedgeley.

Platt, S. R., Abramson, C. J., \& Garosi, L. S. (2005). Administering corticosteroids in neurologic diseases. Compendium, 27(3), 210-220.

Plumb, D. C. (2011). Plumb's Veterinary Drug Handbook (7th ed.). Wisconsin: PharmaVet Inc.

Roberts, I., Yates, D., Sandercock, P., Farrell, B., Wasserberg, J., Lomas, G., Cottingham, R., Svoboda, P., Brayley, N., Mazairac, G., Laloë, V., Muñoz-Sánchez, A., Arango, M., Hartzenberg, Z., Khamis, H., Yutthakasemsunt, S., Komolafe, E., Olldashi, F., Yadav, Y., Murillo-Cabezas, F., Shakur, H., \& Edwards, P. (2004). Effect of intravenous corticosteroids on death within 14 days in 10,008 adults with clinically significant head injury (MRC CRASH trial): Randomised placebo-controlled trial. Lancet, 364(9442), 1321-1328. http://dx.doi.org/10.1016/S01406736(04)17188-2. PMid:15474134. 
Ropper, A. H., Samuels, M. A., \& Klein, J. P. (2014). Adams and Victor's Principles of Neurology (10th ed.). New York: McGraw-Hill.

Royal Canin. (2019). Dog Breed Library. Aimargues: Royal Canin. Retrieved in 2019, June 28, from https://www. royalcanin.com/us/dogs/breeds/breed-library

Sande, A., \& West, C. (2010). Traumatic brain injury: a review of pathophysiology and management. Journal of Veterinary Emergency and Critical Care, 20(2), 177-190. http://dx.doi.org/10.1111/j.1476-4431.2010.00527.x. PMid:20487246.

Schatzberg, S. J. (2010). Idiopathic granulomatous and necrotizing inflammatory disorders of the canine central nervous system. The Veterinary Clinics of North America. Small Animal Practice, 40(1), 101-120. http://dx.doi. org/10.1016/j.cvsm.2009.09.003. PMid:19942059.

Vitale, S., \& Foss, K. (2019). Immune-mediated central nervous system disease: Current knowledge and recommendations. Topics in Companion Animal Medicine,34,22-29. http://dx.doi.org/10.1053/j.tcam.2018.11.003. PMid:30808493. 